Pre-print version: Journal of Applied Research in Higher Education, Vol. 4, No. 2, 2012

\title{
Emotional work: students realising, negotiating and overcoming barriers
}

Wintrup, J., James, E., Humphris, D. \& Bryson, C.

\section{Introduction}

In this paper we present findings from a three-year, longitudinal, qualitative study of health and care Foundation degree students in further and higher education. As mature, working, part-time learners at risk of early departure (Cameron et al, 2010; Yorke and Longden, 2008; Yorke, 1999), we are particularly interested in how their experiences changed over time and the ways in which they persisted despite setbacks and problems. The personal accounts offer insights into the emotional effort expended on peer support, negotiation and resolution of problems. Descriptions of practical and organisational barriers extend our understanding of engagement as a complex, fragile and unstable dynamic. We discuss the contribution of Mann's 
(2008) enabling factors to creating and sustaining a dynamic of engagement in teaching and learning relationships.

Background to study

Foundation degrees were introduced in 2001 to widen participation in Higher Education (HE), facilitate employer-led, work-based learning and promote student employability, particularly in vocational areas of skill shortages (HEFCE, 2000). Increasing the skill-base of support staff in health and social care was recognised by Government as an urgent need (Department of Health, 2006), during a decade of growth and investment shaped by the National Health Service (NHS) Plan (Department of Health, 2000).

The programme was designed to widen access to HE, equip graduates for new, extended roles in health and care settings (Department of Health, 2004) and create pathways for progression to year two of named Honours degrees (including social work, physiotherapy, occupational therapy, nursing, audiology, podiatry).

This dual aim was anticipated as a potential conflict as 'new and broader career possibilities' opened up to work-based students (Fuller, 2001: 246). Both Brain et al (2004) and Little (2005) expressed concern that this duality would mean the qualification was perceived as a stepping-stone only. Foskett (2005:359) 
warned of the risks of misunderstandings created by all parties' 'unarticulated, hidden aims'. Nonetheless, during this period the expectation was that support workers in the health and care sector would soon be able to progress according to ability, no longer constrained by a lack of earlier opportunity.

\section{Literature: Student Engagement}

Student engagement in Higher Education has been a focus of research in the United States, Australia and New Zealand for many years. Tinto's (1993) seminal work on student attrition connected early student drop-out to a lack of integration and involvement. Kuh et al (2008) developed a measure of student engagement through the National Survey of Student Engagement, now undertaken by millions of students in modified forms internationally. Its focus is on the extent to which students are actively involved in 'educationally purposeful' activities, leading to a renewed focus on the curriculum (Kuh, 2008). Although its proponents argued that this serves as a proxy for educational quality, the approach is increasingly influential in policy formation at national and institutional levels.

The concept is gaining ground in the UK, although recent critiques recognised that the broader and more diverse student body, attracted through widening participation, is not well represented in these large cohort studies of traditional student groups (Brunsden et al, 2000; Rhodes et al, 2004). The approach of 
measuring engagement through large scale surveys has also been criticised by Bryson (2011) because it underplays that:

every student is unique and brings different experiences and aspirations to HE (Haggis, 2004)

$\sim$ it is socially constructed and contextualised (Bryson and Hand, 2007)

it includes students' whole lives with social factors impacting on 'academic' engagement (Bryson and Hardy, 2012)

there are powerful alienating forces present in HE which act against engagement (Mann, 2001; Kraus, 2005)

$\sim$ it is a multi-dimensional, dynamic meta-construct which is 'pattern-centred' rather than variable-centred' (Fredricks et al, 2004 inter alia)

\section{Qualitative studies in Student Engagement}

Throughout this discussion, the term 'engagement' is used to reflect both the personal investment of time and energy in other people, objects and activities described by Astin (1999: 518) and the dynamic between student, institution and pedagogy described by Mann (2008: 13), which opens up or liberates potential, opportunity, confidence and ways of thinking and knowing. Mann $(2001,2008)$ explored how power, manifested through structures, processes and discourses, influences such an engagement or leaves students feeling unable to invest or 
contribute in ways which are meaningful and productive. She defines this experience as alienation: feeling 'held back, blocked, inhibited, estranged or isolated' (Mann, 2005: 43). In a similar vein, Ylijoki (2000) considered the pressure students may feel to conform to an existing moral order. Once alienated, or in a state of 'inertia' as Krause et al (2005) preferred to consider it, students are at a greatly increased risk of withdrawing and leaving university; she found students battled with values and rules which they saw as incompatible with their own. Mann (2001) speculated that such a persistent yet alienated stance is a 'survival strategy'; less painful than further rejection or failure.

Both suggested ways of creating conditions for engagement, more systematically and purposefully. Mann (2008) discussed 'enabling forces' which institutions might realise. Hockings (2010) too has argued that a student centred approach is not enough; teachers need to create dialogue with students to discover and respect their diverse experiences and knowledge. Bryson and Hand (2007) particularly emphasised the salience of trust relationships. Mann's (2008, p. 138) five enabling forces of the institution (data in the list adapted from original source):

1. purpose: as the enablement of critical being (Barnett, 1997); 
2. ethics: creating an ethic of care, manifested in providing opportunities for students to learn and in "treating each other well";

3. inquiry: inquiry-based practice, both content and practicefocused, which attends to multiple voices and asserts the human over the programmatic;

4. dialogue: "moral conversations" which challenge existing positions and imagine future identities (Benhabib, 1992, p. 8);

5. resources: creation of time and space to support dialogue, negotiation, decision making and inquiry.

Foundation degree research

Concerns about poor retention continue and influenced much of this research (HEFCE, 2010), which is usefully critiqued by Harvey (2010).

Similar themes emerge across Early Years Foundation degree studies, which are largely qualitative in nature. Students identified transition problems from Further Education to HE as stressful because of less time and support from lecturers (Greenbank, 2007). Goddard et al (2007) found students to be anxious when faced with lengthy written assignments. A more 
'hands-off' approach at the beginning of second year was found by Knight et al (2006: 6) to cause some to feel 'abandoned'. The same study followed students who had dropped out of university and found stress to be a major contributor. Researchers summarised the problems as: students feeling unable to meet the demands of the programme, facing workplace barriers to study, all compounded by an underlying lack of support from the institution, tutors and peers (Knight et al, 2006).

When viewed through the lens of student engagement, this experimental new programme, designed to open doors and increase opportunity, risked creating new forms of alienation.

\section{Methodology}

Context, purpose and theoretical stance

The research was funded by a Lifelong Learning Network (LLN); a national initiative funded through the Higher Education Funding Council for England (HEFCE). Its purpose was to learn about the student experience of a new HE qualification, with an experimental pathway design for new extended work roles and access to professions. Within a larger team, we (JW, DH) were initially involved in the design and delivery of the programme. A part-time, dedicated Senior Research Assistant (EJ) was appointed to lead the project and data collection. Organisational and personal changes in 2008/9 meant a new team led the 
programme from that point on, since which time the three of us worked together on the research project only.

As educators and researchers we maintained a working knowledge of the programme and sense of involvement with students and colleagues. The identity of 'insider researcher' does not capture the multiple roles and responsibilities we variously occupied during the study period (EJ maintained a consistent role as researcher). Within a social constructionist perspective, such an involved stance becomes an opportunity to engage with others as 'knowing subjects' (Prior, 1997), understanding that all parties are participating in ways which are purposeful and portray themselves as 'morally responsible' (Silverman, 2006:139). A helpful way of viewing this relationship is offered by Narayan (1993: 671) when she places above the identity of the researcher their position in relation to those being researched, asking: 'are they accepted as subjects with voices, views and dilemmas people to whom we are bonded through ties of reciprocity?' Our stance throughout, then, is one of wishing to reciprocate by giving voice to participants' words and experiences while offering a critical interpretation.

\section{Ethics}

The practical ethics of our involved stance thus required a robust ethical framework: to protect participants' and colleagues' identities and maintain a separation between educational factors 
and confidential research data. EJ became entirely responsible for all aspects of data collection, anonymisation, codes and storage. This was explicit in information and consent procedures. Ethical approval was gained from the School of Health Sciences Ethics Committee in 2007. NVivo was used for analysis and theme development.

Small numbers necessitated further anonymisation of data to reduce the likelihood of identification of individuals by others while accepting that participants may recognise their own words. We present interviews simply as 'year 1 ' and so on, rather than the actual year of entry. Personal characteristics are sacrificed for the same reason. The decision not to compromise anonymity by linking personal information (including demographic and progression data) with participants' words, imposes limitations on the current analysis. For example, it prevents analysis of experience by individual educational achievement (such as comparison of a participant's grades achieved over time or through difficult periods) or by sub-group (gender, age or prior educational achievement) and limits any broader generalisation to categories of student. To do justice to the combined dataset, a further analysis is underway which looks specifically at entry, progression and graduation details, in relation to characteristics and themes from interview analysis.

Study design and methods 
A cohort design allowed us to follow student journeys as year groups, through pathways and on into other programmes. In total thirty-seven students participated, taking part in one, two or three interviews spaced approximately one year apart and undertaken towards the end of each academic year (see Table I). In total, sixty-five interviews were conducted. Most students were on a two year programme but third interviews were possible with those on a part time route or on Honours programmes.

Students who entered HE between 2007 and 2010 were invited to take part (total entrants 60 per intake). Semi-structured interviews lasting between one and two hours followed a schedule (see Table II). The schedule was adapted for subsequent interviews to allow new issues to be raised. Between interviews, EJ kept in touch with participants and saw them intermittently. Initially thematic analysis was used, drawing on research findings around the transformative power of education and the importance of peer support and a sense of belonging (Wintrup and James, 2008). Later interviews were more difficult to analyse however as they told many different stories. It is only since data collection ended that we have been able to isolate clusters of interviews according to individuals, cohorts and years and reanalyse data using a more grounded approach. The analysis is not concerned with which calendar year or cohort students belong to; we are interested in their first, second or third year experience. 
Broader themes connected with enabling factors and barriers emerged, which we found to be well explored in student engagement research and findings are discussed in light of this. Table I shows numbers of participants and interviews. Only words from those who undertook two or three interviews are used (shaded in grey), meaning that words from a potential 20 participants are drawn from 48 separate interviews over two or three years.

Table I: Number and distribution of interviews and interviewees

\begin{tabular}{|l|l|l|l|l|}
\hline & $\begin{array}{l}\text { Cohort 1 } \\
2007 / 2008\end{array}$ & Cohort 2 & $\begin{array}{l}\text { Cohort 3 } \\
2009 / 2009\end{array}$ & $\begin{array}{l}\text { Total } \\
\text { participants by } \\
\text { year }\end{array}$ \\
\hline Year 1 & 5 & 17 & 15 & $\begin{array}{l}37 \text { Year 1 } \\
\text { participants in } \\
\text { total }\end{array}$ \\
\hline Year 2 & 4 & 11 & 5 & $\begin{array}{l}\text { 20 of the } \\
\text { original 37 } \\
\text { participate in } \\
\text { Year 2 } \\
\text { interviews }\end{array}$ \\
\hline $\begin{array}{l}\text { Year 3 } \\
\text { Yotal number of } \\
\text { interviews by } \\
\text { cohort }\end{array}$ & 9 & 8 & $\begin{array}{l}\text { 8 of the 20 Year } \\
\text { 2 interviewees } \\
\text { participate in } \\
\text { year 3 } \\
\text { interviews }\end{array}$ \\
\hline
\end{tabular}

Of the 37 participants, four were male and six were not originally from the UK. Ages ranged from mid twenties to early fifties. Ten 
started their programme at a local Further Education College.

Students' words are reproduced verbatim, but again to seek to protect identities, occupational programme titles are replaced by 'professional'.

\title{
Table II: Semi-structured interview schedule
}

\begin{abstract}
We'll start by talking about what led you to taking up the Foundation degree - can you tell me a little about what work you do, and how you heard about the programme[....]? Subsidiary questions, working life, hopes and plans, family considerations as appropriate

Can you remember what you expected or thought it might be like? Subsidiary questions about learning experiences in the past, training

What did you hope the studying would be like? Has it been as you expected / hoped? Subsidiary questions about learning experiences, what has it been like, what has been helpful, unhelpful?

Can you tell me about the work placements?

Can we talk about your plans for Year 2 (or Year 3 or following study) Subsidiary questions around changes in plans, hopes, aspirations

Have those plans changed? If so what are the most significant changes? Have you changed over the last year? In what ways?

Is there anything you would like to talk about, anything we haven't touched on? Subsidiary questions as appropriate
\end{abstract}

Note: In second and third interviews, prompts or reminders might be offered from previous interviews such as "You wanted to take the physiotherapy pathway last year - what changed?"

\section{Findings}

First year interviews

First interviews were generally carried out towards the end of year one, either just before or just after final assignments. This was for practical reasons but also to enable a reflective look back 
at the experience. Many described a lack of information and a wide range of expectations. For example, this person felt unprepared for the academic aspect of the degree: 'I didn't come on the course to learn about theories' $(K)$. Work placements also presented challenges: 'I found it quite difficult, the interviews, everything, we went to all sorts of children being abused, homes, families and it was quite difficult' $(S)$.

However both the academic stretch and work placements were more often seen as positive, essential to learning and even lifechanging: 'Searching for articles and information...is absolutely ground-breaking for me, because it had enabled me to know how to search ...rather than taking everything at face value' (T).

Several expressed pride and a sense of anticipation, expressed by this participant: 'Once I finish this and have got over the stresses of it, I'll be looking for the next thing I can do and I think it will carry on for a long time... I will get a huge, huge amount of satisfaction and pride of knowing that I will have been the first person in our family to do a degree' $(U)$.

Another who had not contemplated university found she was discovering new career possibilities not previously open to her simply because she had never known about them: 'FE was never an option, my family didn't have the money to support me through uni and it was never mentioned' and yet 'It's opening up areas which I wouldn't even have considered at the beginning of 
the year, because I didn't know they were out there' ( $O$ ). Discovering such possibilities was exciting for many.

Others blamed themselves for a lack of knowledge: 'I don't think we fully realised how much emphasis there would be on selfdirected study... it's so different in Further Education...' (U). Following a difficult encounter during a group project, another said: 'That's one example, it happened a few times with different people. I think that's something to do with me as well, the way I am, makes some people treat me that way' $(V)$.

Nonetheless optimistic and problem-solving approaches prevailed, supported by the development of close friendships and highly supportive study and social groups: 'The friends, or colleagues, that I was on the course with, we all supported each other. We used to thrash things out. Outside of work, in our own time' $(F)$ and 'It's nice because if ever you feel you are falling back, or you miss something, you know someone else is going to be there to help you and bring you back up' (D).

Previous poor experiences, particularly at school, were very common: 'I remember being written off quite early... I think that stays with you and that carried on' (T). This student describes her growing confidence being supported by specific and constructive feedback advice: '... and that was nurtured by the feedback, you know when you get feedback and it's positive, and "if you did this 
then you would bring your mark up" then you can realise... and that sort of drove me on really...' (T).

As a main plank of the widening access to professions agenda, several second year options were taught in other Academic Schools alongside full time first year students. For practical and funding reasons numbers on professional pathways were restricted and competitive, meaning places had to be applied for and managed by admissions tutors. The process started shortly after Christmas in the students' first year and one interviewee just found this too early: 'I didn't want to enrol on something I would be stuck on' (O). For many this was stressful and brought back fears of inadequacy: 'I decided right at the last minute, because I wasn't sure I was capable of doing it, or had the intelligence to do it' $(V)$. Another describes the very information-giving process as worrying: 'She's actually a lecturer on the (professional) course, someone arranged for us to meet her, and she did, she said "I am kind of here to put you off" and told us what the course was, what the essays were, statistics... which I was very scared and worried about' $(V)$.

So themes to emerge from first year interviews reflected previous Foundation degree research, in that several felt ill prepared for $\mathrm{HE}$ and many doubted their ability. In general though, reflections were positive particularly about new experiences and opportunities. Pride and a sense of having achieved something 
important was a motivating factor, as were supportive social relationships. Pathway choices were experienced as stressful for some and the decision time was too early for one participant.

\section{$\underline{\text { Second year interviews }}$}

For all participants, the second year was more difficult; the novelty of being at University had worn off and pressure of study had increased. Several described considerable stress to the point of having wanted to leave. The pathway model meant that closeknit first year friendship groups found themselves in different schools, buildings and Faculties, now having to negotiate all parts of the university rather than one small campus or college. All had to get to know new people. While transition into the programme appears not to have been particularly traumatic, as worry was ameliorated by new friendships and anticipation, the move from first to second year was complicated and problematic for several:

'There was quite a lot of unhappiness at the start of year two' (D).

'The second year... was hard. Stressful, because I was still working, and the assignments I found, were much more in-depth, and the memories I have first and foremost, being in tears most of the time, saying I can't do this. Well actually I couldn't do it' (U).

Interviews gave scope to explore this disjuncture. Participants variously discussed different teaching approaches, getting used to new lecturers and the need to adapt to new teaching styles: 'This 
year, being a completely new set of lecturers, you had to learn about what their expectations were. And although academically it should be in line, there are differences, with what lecturers (give) weight, which is why feedback is so important' (T). Another was critical of style: 'I just felt that in a large group (the lecturer) didn't relate very well' $(P)$. She also felt a need for a more 'student friendly' teaching approach: 'particularly for students who are quite scared of academics, which most of them - which most of us $-\operatorname{are}^{\prime}(P)$.

Others described withdrawing, not because of fear but an unwillingness to disturb busy people: 'I think they were there if you needed to ask them something, but I just got on with it really. I didn't feel like I wanted to bother them, they were very busy ...' (D).

Many discussed feedback as generally encouraging and helpful, but for the following interviewee it was pivotal in her staying the course: '... and the lecturer had written "it is obvious you find this very difficult to write, and you will make a very good (professional)". So I'm trying to hold on to these bits, to get me through, because I was, at different times, very, very upset' (V). She felt her work placement feedback in particular helped her get through difficult periods: '... and certainly, if I hadn't had those two placements, and with that recommendation from the 
(professional) in that school "I think you'll be a really good (professional)", I would have given up by now' (V). A more relaxed approach is in evidence too though, as another describes: 'I'll be honest, first I look at the mark, and if the mark's reasonable then I kind of skim read the feedback' $(P)$.

By far the most common theme in second year interviews was the frustration caused by not having adequate information about timetables and room changes. One, who had considered leaving and briefly did so, thought her lack of assertiveness might have contributed to the problem: 'It's not all someone else's fault; there are things I could have done about it. I could have insisted, I could have stood there and said "I'm not going until I get a timetable"' although she says later 'I didn't have it in me to insist' $(R)$. However for another, asserting her needs was unavoidable: 'Three of us, we've had to really fight for it, for the course really, just to get from lectures to seminars to everything else...and we've had to fight for everything..it was so annoying, it was so, that, I nearly gave up' (S). Another resented the intrusion through a break: 'Even in the Summer, we had to sort stuff out.. I got very angry at times, I didn't want to feel that way, and I kept getting emails..we were having exams and essays to write - it went on the whole year - (indicates thinking) "No it's not my job, I don't work for the University"' (V). Many other milder but significantly frustrating experiences were recalled and will be discussed later. 
In terms of motivation, a more grimly determined narrative replaced the earlier optimism, as some described the absolute necessity of persevering and succeeding. A single mother with many family pressures and adapting to life in the UK, described her reasoning: 'I had to do it. I think my love to my children, because I wanted to get a better job, with a career, to have a better life for them. I keep saying "If I graduate, I get a better job, I get better money so I can do whatever they want, build their future"' (Q). In similar vein, another recalled: 'It's just the determination to prove that I could do it. I didn't want to, you know pack it in halfway through the course because I would have felt as if I'd failed again. I had to do it, it's proving it to myself again. So that's what kept me going' $(F)$.

\section{Third interviews}

Participants were interviewed at different points during their third year at university. Generally they were now on a new degree programme although one was completing the final year of a parttime route through the Foundation degree (R). Most intended to go on to further study following their current programme, showing high levels of motivation. One said of her current progress towards a professional qualification 'I really want it so badly' (D) while another confirmed: 'I'm here for the long haul... if that means throwing yourself in 100\% then you have to' (P). 
The part time student had gained a place on a Master's degree at another university on the strength of the Foundation degree and work experience and planned, like many others, to go further: 'The grand plan! ... I know I have a question in mind and I know that my ultimate goal is to do the PhD... yeah I do intend to continue' $(R)$. In the same interview, she reflected on the point when she had dropped out of her studies: 'probably about this time last year, I'd got so fed up with the admin problems and timetabling issues, I actually said, I don't want to do this anymore'. (R). When she contacted the programme lead she was encouraged to resume her studies and found a high level of support to do so.

Without exception the Foundation degree was seen as an important gateway to future possibilities. One said: 'the Foundation degree lets down a ladder that you can climb up' (T). But she remembered fear of being 'exposed' as someone who should not be in HE and of 'letting down' her employer. The sense of gratitude to the NHS employer remained with another: 'I just felt as though I was grateful that they were sending me. I couldn't have done the Foundation degree without the organisation paying and releasing me' (D).

A lack of knowledge of processes remained a problem though: 'I do regret, that in year 2 you are so wound up with thinking about getting through year 2 , you actually don't think "oh we need to 
start applying through UCAS for different courses", so by the time, you know...' (T). Another discovered too late: 'for part time (professional degree) you don't apply through UCAS... so I spent from June until Christmas getting really anxious, until somebody finally said to me..' (P).

An international student reflected on her relationships with peers: 'in my class everybody was nice to me, but I think when you are from the minority ethnic you always feel as though there is a wall between you and other people' (Q). The part time student also recalled feeling lonely after friends had graduated, saying 'I have no friends and nobody else in the group to talk to, or say "what was your understanding of ..."' (R). Q concludes: 'in the end I am thinking "it's me only, I am on my own, I have to do it"'. A sense of not 'fitting' with university procedures persisted during induction to the new degree for P: 'they assume everyone's 19 and lives on campus...I found that really frustrating in the transition programme!'

Nevertheless a powerful sense of personal change and heightened awareness permeated later interviews, captured in words such as 'It's broadened and deepened my perspective on society and how things work - on the big picture really' $(L)$. Another felt she was 'a better person' and wanted to be 'the best I can be' (D). K felt it had 'opened her eyes' and like many others through all years, was now much more questioning: 'I don't just want to know the 
surface, and know my job, I want to know underneath why I'm doing that, where does that come from, who said we had to do it like that' $(\mathrm{K})$. But a broader and deeper perspective meant a different, possibly less comfortable outlook on life: 'It's made me angry about things as well, physically I'm afraid, but maybe that's a good thing, I don't know - shouting at people on the radio at $8 \mathrm{o}$ clock!' (L).

Despite such personal growth and broader horizons, frustrations were still evident and focussed on a lack of knowing about processes, now in a context of feeling more alone. One spoke of postponing her plans so she could begin the Honour's degree with a friend. Others discussed the much larger, lecture-focussed format being a shock after the smaller group sizes of the Foundation degree. The experience of the student from a minority ethnic group is of feeling not just alone but that a wall exists between her and others, after three years of study.

Negotiating and confronting barriers

All participants talked of the goal of achieving their degree or professional qualification as a powerful motivator for remaining on the course of study. Of those who talked very seriously of contemplating giving up their studies, very similar things influenced their decision to carry on. First and foremost, support from and for each other manifested in telephone calls, group and individual meetings or ongoing supportive conversations often 
via social media. This mutual encouragement and support emerges as one of the strongest themes of the study, across all three years and was reported amongst pathway networks as well as friendship groups: 'I spend more time away from campus ... but the girls that I went with onto the (professional) degree we've been really supportive of each other, because it's been really, really tough we've kind of bonded together' $(S)$.

Following her own difficult patch, a student describes determinedly supporting others: 'And I think a couple of people on my course were going “I don't want to do this anymore, I'm going to give up". (enacts) "Oh no you don't give up! You're not!" and you sort of help them out there...' (O).

In similar vein, a student describes a wholly supportive response from a tutor when family problems threaten to become overwhelming: 'I didn't say much to tutors or anything, until it got a little bit too bad, and then it was quite obvious all was not right, and I spoke to (lecturer) and she was brilliant, she just said "take time out, take as much as you need... you need a break, just go and we'll sort things out" $(O)$. Struggling to balance study and work - a common problem - was eased by a supportive employer: 'I nearly came a cropper with my academic work, and was really stressed and thought "this is too much", so I saw my boss, and dropped my hours' (L). 
Although the prevalent response to contemplating leaving the course was to seek support from friends on the programme, some more detailed accounts are given in second year interviews. A student who was also a course representative describes both struggling herself and feeling overwhelmed by the needs of peers: 'There was one point, around February or March in the second year, I thought "I'm never going to get through this". As the course rep I contacted course leaders and said "Look this is just...” I was getting phone calls from other people saying "I can't cope with this, there's too many things all due in at the same time"...so we did get an extension for one of them, it was a big help. And to be fair, when there was a problem, the lecturers were very understanding' $(U)$.

When an assignment brief was unclear, collective action was taken by the whole group, leading to a swift response and an apology by the programme team which, from one student's perspective at least, restored a sense of equilibrium straightaway: 'We felt bewildered at the beginning. And then we all started realising that actually we had voices. So when we all decided to say something, it was brushed under the carpet at first, and then suddenly, it was recognised and apologies were made, and that was appreciated. That was really appreciated. And then we seemed all right again. We seemed to be okay again' (K). 
So participants describe peer support as the option of choice, followed by their course representative, individual tutors and employers, and then module or programme lead when all else fails. Nonetheless all their reported efforts were highly successful. While such a collective self-sufficiency can be seen as a very positive response, it also raises the question: why did problems have to escalate before lecturers / tutors were contacted? This will be returned to in the discussion. The social and collective nature of their response also causes us to ask whether the more socially isolated students were raising issues when they needed to, and whether those who earlier described feeling more alone, would respond differently when not secure in a social network.

\section{Discussion}

Like the definitions of student engagement that call for an understanding of its socially derived and contextualised nature, our participants' accounts show that it is simply not possible to get it right for everyone, all of the time. Yet there are some consistent themes through data, over time and across cohorts, which offer us important salutary insights.

Even these highly motivated and persistent students, who go on to succeed by any traditional measure of academic achievement, talk of dark periods, of wanting to leave but feeling desperate to qualify, of feeling alone yet preferring not to bother busy staff. None of us want to think of 'persistence' in HE as being locked in a 
loveless embrace, yet at its worse, this is what some describe. When asked for help, individual lecturers and personal tutors responded swiftly and caringly, yet so many participants were reticent to approach them. The casual assumption by an interviewee that all students are scared of lecturers is troubling considering their life experiences and work accomplishments.

So themes to be discussed, in light of Mann's (2008) enabling factors, are: the students' use of peer support which plays a part in persisting in their studies and leads to collective action; the institutional barriers manifested in a lack of efficient processes and the alienating effect on students; and the development of a critical stance and a renewed sense of self, expressed in hopes and plans for the future.

\section{Peer support}

It is difficult to do justice to this theme as it forms a backdrop to every interview. Even those who described feeling alone talked of previous good experiences. Participation in the research activity may have attracted the most social individuals (a real possibility) and caring work is a social activity. However it is hard to ignore the power of such a naturally occurring and successful form of peer engagement. When serious problems arise, the social groups mobilise, acting collectively, in one instance through the course representative but in the other, seemingly spontaneously in a taught group. The much smaller pathway group of three 
overcame distance to speak via social media, actively supporting each other to persist. It is possible, even likely, that such determined support and bonding came from feeling marginalised; not part of a valued profession, or of the academy.

We ought not to assume, either, that social group membership was a universal good, enjoyed by all. Students who left early or did not take part in the research may have had a very different experience. It is possible that those in social groups did not notice, or choose to discuss, those not socially included (such as Q who talked of a 'wall').

Prentice (1999) described new entrants to HE having to 'prove' their ability and value to established members of the academy rather than being welcomed; the politically-driven Foundation degree challenged both established professional and academic values and practices. For all these reasons we might usefully revisit the conditions created by the institution to support students at particular risk of not feeling part of HE - and indeed how it came to be that in our research, staff appear to have played no part (with the important exception of a Further Education College tutor).

\section{Institutional barriers}

Students' accounts of 'fighting' to get information simply to 'be' students are difficult to read. Pathways to widen access were 
forward-thinking and successful in their ends, yet we seem to have asked too much of the means - technological and human systems designed around traditional three year degree programmes. Rather than crossing bridges, students describe finding themselves in a 'no-man's land'.

Had we presented progression figures alone, the story would be one of unparalleled success, widening access to already oversubscribed, high status professional programmes. But for the students' accounts, the story might have ended there. Instead we are helped by Mann (2008) to place care at the top of the hierarchy of objectives when creating new opportunities. Bureaucracy then becomes interesting as a force for enabling creativity. People and systems only become a resource to students when fused together by intention, purpose and action.

\section{Development of a critical stance}

The many descriptions of students becoming questioning and curious are also difficult to do justice. Later interviews abound with examples of students being questioning. The will to learn is evident but as Barnett (2007) describes, it is fragile, becoming only slightly more robust over time and contingent upon friendships and belonging (in the wider sense). Of course students were already curious and thoughtful people - now they have access to privileged 'professional' knowledge. But remembering the knowingness of our 'subjects' (Prior, 1997) we 
can expect them to describe this valued quality in interviews. This makes their accounts of action interesting.

That they eventually acted on course-related problems, individually and collectively - and when and how they decided to take action - provides a timely reminder that mature, working students manage change and conflict all the time. It is important to speculate on what it was about their encounter with HE that contributed to so many avoidance or withdrawal tactics, rather than the more robust, critical stance taken later on.

To answer this, we might usefully remember the gendered, lowstatus and hierarchically-ordered nature of caring work. Colley (2006) reminds us of the unwritten curricula, that requires the cost of 'emotional labour' to be born quietly and 'correctly'. Caring can be confused with self-sacrifice, meaning our responsibility in such education is to invite and scaffold a critical take on care within its political and societal context. Participants who speak of having new ambitions embody an invigorated sense of self. Those who talk of wanting to know why they are doing their job in a particular way, or of no longer taking things at face value speak as critical beings now sustained and energised by the right to question and challenge (Barnett, 1997). Caring work needs more than ever such a questioning and confident stance. 


\section{Conclusion}

We might conclude by listing the experiences participants found alienating, and by recommending ways in which institutional processes, systems, policies and people become more proficient in enabling students simply to be students, given that their work is to learn. We could echo Kift et al (2010) and others, who recommend a whole-institution approach to the first year experience, making time and space within curricula for bonding activities which are structured and inclusive, not spontaneous and fortuitous for some. Finally we could advocate for a critical engagement with pressing environmental, political and social challenges, as Barnett (1997) does. However the case for this kind of active engagement has been made well and often, and by now should be a given, part of all education for all students.

Instead we pose the question to fellow educators: if engagement is understood as a dynamic relationship between the student, the institution (with its systems and policies) and the teaching and learning practices, how can we best promote such a dynamic? of Mann's (2008: 138) 'enabling forces' two in particular speak to the issues raised in this study: developing an ethic of care, and promoting dialogue.

Mann (2008: 130) quotes the poet Adrienne Rich (1986): 
'When those who have the power to name and to socially construct reality choose not to see you or hear you, whether you are dark-skinned, old, disabled, female or speak with a different accent than theirs, when someone with the authority of a teacher, say, describes the world and you are not in it, there is a moment of psychic disequilibrium, as if you looked into a mirror and saw nothing'.

As mature, working, part-time learners with predominantly vocational qualifications, the Foundation degree students were not as present or visible as others and as if to reinforce a sense of invisibility, some experienced not being included on basic communication lists. Programmes established to enable them to succeed require an ethic of care, which extends beyond personal relationships, responsiveness or kindness, to one of confident advocacy; seeing the students' wellbeing and achievement holistically, and central to decisions, policies and procedures which affect them.

Such an ethic depends upon a broader culture of respect and collegiality, which is communicated proactively through personal tutors, lecturers and increasingly professional / administrative staff. This, in turn, depends upon having emotionally engaging dialogue with and amongst students (Wintrup, 2009), which promotes trust (Bryson and Hand, 2007) and respects diversity (Hockings, 2010). Benhabib (1992: 8) describes ‘a moral 
conversation, in which the capacity to reverse perspectives, that is, the willingness to reason from the others' point of view, and the sensitivity to hear their voice is paramount'. All communications - perhaps most importantly, assessment and different types of feedback - provide an opportunity to embody such a dialogical approach.

Together such enabling factors make more likely the development and reinforcement of a student's sense of self, as a valued member of a learning community, intellectually capable, with a unique contribution to make. To become embedded institutionally, the language of liberating potential, opportunity, confidence and ways of thinking and knowing (Mann, 2008) might usefully permeate not only formal policy and assessment / feedback processes, but the lived, practical, every day experiences of students.

\section{References}

Astin, A.W. (1999), "Student Involvement: a developmental theory for Higher Education", Journal of College Student Development, Vol. 5 , No. 5 , pp. $518-529$.

Barnett , R., (1997), Higher Education: A Critical Business, Open University Press and Society for Research in Higher Education, Maidenhead. 
Barnett, R., (2007), “A Will to Learn: Being a student in an age of uncertainty", Open University Press and Society for Research in Higher Education, Maidenhead.

Benhabib, S. (1992), Situating the Self: gender, community and postmodernism in contemporary ethics, Cambridge, Polity Press.

Brain, K., Layer, G., and Reid, I., (2004), "Solid bedrock or shifting sands? The risky business of laying foundations", Journal of Access Policy and Practice, Vol. 1, No. 2, pp. 134 - 150.

Brunsden, V., Davies, M., Shevlin, M. and Bracken, M. (2000) "Why do HE students drop out? A test of Tinto's model”, Journal of Further and Higher Education, Vol. 24, No. 3, pp. 301-310

Bryson, C. and Hand, L. (2007), "The role of engagement in inspiring teaching and learning", Innovations in Teaching and Education International, Vol. 44 No. 4, pp. 349-362.

Bryson, C., (2011), "Clarifying the concept of student of engagement: A fruitful approach to underpin policy and practice", Paper presented at the HEA Conference, Nottingham University, 5-6th July 2011.

Bryson, C. and Hardy, C., (2012), The nature of student engagement, what the students tell us, in Solomonides, I. Reid, A. 
and Petocz, P. (eds) Engaging with Learning in Higher Education, London: Libri.

Cameron, J., Roxburgh, M., Taylor, J. and Lauder, W. (2011), "Why students leave in the UK: an integrative review of the international research literature", Journal of Clinical Nursing, Vol. 20, Issue 7-8, pp. 1086-1096

Case, J. (2007), “Alienation and engagement”, Teaching in Higher Education, Vol. 12, No. 1, pp. 119-133

Colley, H., (2006), "Learning to labour with feeling: class, gender and emotion in childcare education", Contemporary Issues in Early Childhood, Vol. 7, No. 1, pp. 15 - 29.

Department of Health, (2000), “The NHS Plan”, available at http://www.dh.gov.uk/en/Publicationsandstatistics/Lettersandc irculars/Dearcolleagueletters/DH_4010516 (Accessed 14th February 2012).

Department of Health, (2004), "Agenda for Change”, available at http://www.dh.gov.uk/en/Publicationsandstatistics/Publications /PublicationsPolicyAndGuidance/DH_4095943 (Accessed 14th February 2012).

Foskett, R., (2005), “Collaborative partnership in the higher education curriculum: A cross-sector study of Foundation degree development", Research in Post-Compulsory Education, Vol. 10, No. 3, pp. $351-72$. 
Fredricks, J., Blumenfeld, P. and Paris, A., (2004), "School engagement: Potential of the concept, state of the evidence", Review of Educational research, Vol. 74, No. 1, pp.59-109

Fromm, E. (1978). To have or to be? London: Jonathan Cape.

Fuller, A., (2001), “Credentialism, adults and part-time higher education in the United Kingdom: an account of rising take up and some implications for policy", Journal of Education Policy, Vol. 16, No. 3, pp. $233-248$.

Goddard, G., and Penketh, C., (2007), "Students in transition: foundation degree to honours level 6, a narrative journey of development", paper presented at British Educational Research Association Annual Conference, Institute of Education, $5^{\text {th }}-8^{\text {th }}$ September 2007.

Greenbank, P. (2007), "From Foundation to honours degree: the student experience”, Education and Training, Vol. 49, No. 2, pp. 91 $-102$.

Haggis, T., (2004), “Meaning, identity and 'motivation': expanding what matters in understanding learning in higher education?", Studies in Higher Education, Vol. 29, No. 3, pp.335-352.

Hardy, C. and Bryson, C. (2010) "The Social Life of Students: support mechanisms at university", $14^{\text {th }}-16^{\text {th }}$ December 2010, Presented at the Society of Research into Higher Education Conference, Celtic Manor, Wales. 
Harvey, L., (2010), "Review of Research Literature Focussed on Foundation degrees", available at http://www.heacademy.ac.uk/assets/documents/fdf/Review-ofresearch-literature-focussed-on-foundation-degrees.pdf (Accessed 14th February 2012).

HEFCE (2000) "Foundation degree Prospectus" available at http://www.hefce.ac.uk/pubs/hefce/2000/00_27.htm (Accessed $14^{\text {th }}$ February 2012)

Hockings, C., (2010), "Reaching the students that student-centred learning cannot reach", British Educational Research Journal, Vol. 35, No. 1, pp.83-98.

Kift, S.M., Nelson, K.J. and Clarke, J.A. (2010), Transition pedagogy: a third generation approach to the First Year Experience: a case study of policy and practice for the higher education sector. The International Journal of the First Year in Higher Education, Vol. 1, No. 1 pp. 1 - 20. Available at http://eprints.qut.edu.au/33635/1/c33635.pdf (Accessed 2nd May 2012)

Knight, T., Tennant, R., Dillon, L., and Weddell, E., (2006), "Evaluating the Early Years Sector Endorsed Foundation Degree: A qualitative study of students' views and experiences", available at https://www.education.gov.uk/publications/standard/publicatio nDetail/Page1/RR751 
(Accessed on 14th February 2012).

HEFCE, (2010), "Foundation degree Key Statistics", available at http://www.hefce.ac.uk/pubs/hefce/2008/08_16/ (Accessed 14th February 2012).

Krause, K. Hartley, R. James, R. and McInnis, C. (2005) “The first year experience in Australian universities: findings from a decade of national studies", available at http://www.griffith.edu.au/_data/assets/pdf_file/0006/37491/ FYEReport05.pdf (Accessed 14th February, 2012)

Krause, K., (2005), “Understanding and promoting student engagement in university learning communities.", Keynote address at Hames Cook University Symposium, Queensland, Sept $29^{\text {th }} 2005$.

Kuh, G. (2008) "High impact practices. What they are, who has access to them and why they matter?", available at http://www.neasc.org/downloads/aacu_high_impact_2008_final. pdf (Accessed 12th February 2012).

Kuh, G. D., Kinzie, J., Buckley, J., Bridges, B. and Hayek, J.C., (2008), "What matters to student success: A review of the literature", ASHE Higher Education Report. Jossey-Bass: San Francisco 
Little, B., (2005), "Policies towards work-focused higher education: Are they meeting employer's needs?", Tertiary Education and Management, Vol. 11, No. 2, pp. 131 - 46.

Mann, S. (2001) "Alternative Perspectives on the Student Experience: alienation and engagement", Studies in Higher Education, Vol. 26, No.1, pp. 7-19.

Mann, S. (2005), "Alienation in the learning environment: a failure of community?", Studies in Higher Education, Vol. 30, No. 1, pp. 4355.

Mann, S., (2008), Study, Power and the University, McGraw Hill, Society for Research into Higher Education and Open University Press.

Narayan, K., (1993), "How native is a 'native anthropologist? “ available at http://schwarzemilch.files.wordpress.com/2009/02/narayan.pdf (Accessed on 14th February 2012)

Prentice, D.A., (1999), Cultural Divides: Understanding and overcoming group conflicts, NY: Russell Sage Foundation.

Prior, L., (1997), In Denzin, N.K. and Lincoln, Y.S.(Eds), (2000), Handbook of Qualitative Research, London: Sage. 
Quality Assurance Agency, 2004 / 2010, "Foundation degree Qualification Benchmark", available at http://www.qaa.ac.uk/Publications/InformationAndGuidance/D ocuments/Foundation-degree-qualification-benchmark.pdf (Accessed 14th February 2012).

Rhodes, C. and Nevill, A., (2004), “Academic and social integration in higher education: a survey of satisfaction and dissatisfaction within a first year education studies cohort at a new university", Journal of Further and Higher Education, Vol. 28, No. 2, pp. 179193

Rich, A. (1986), Blood, Bread and Poetry: Selected Prose 1979 1985, London: Virago.

Tinto, V., (1993), Leaving College: Rethinking the Causes and Cures of Student Attrition, Chicago \& London: University of Chicago Press.

Tinto, V., (2006), "Research and practice of student retention: what next?", College Student Retention, Vol. 8, No. 1, pp.1-19.

Wintrup J., and James, E. (2008), "Personal change, job prospects, learning to ask why: students' reflections upon the worth of their Foundation degree", Paper presented at Society for Research into Higher Education Postgraduate and Newer Researchers 
Conference, Liverpool, UK, 08 Dec 2008. Available at http://eprints.soton.ac.uk/cgi/search/simple?q=wintrup\&_action _search.x=12\&_action_search.y=8\&_action_search=Search\&_actio n_search=Search\&_order=bytitle\&basic_srchtype=ALL\&_satisfyall $=$ ALL (Accessed 14th February 2012).

Wintrup, J. (2009), "A review of ethics education in healthcare literature and the case for a dialogical pedagogy", Paper presented at Philosophy of Education Society Australasia, Hawaii, USA, 04 - 07 Dec 2009. Available at http://www2.hawaii.edu/ pesaconf/Frid.html (Accessed 2nd May 2012).

Ylijoki, O-H. (2000) "Disciplinary cultures and the moral order of studying - a case of four Finnish university departments", Higher Education, Vol. 39, No. 3, pp. 339-362.

Yorke, M. (1999), Leaving Early: Undergraduate Non-completion in Higher Education, London: Falmer Press.

Yorke, M. and Longden, B. (2008), "The first-year experience of higher education in the UK" available at http://www.heacademy.ac.uk/assets/documents/resources/pub lications/FYEFinalReport.pdf (Accessed 14 ${ }^{\text {th }}$ February 2012) 